ISSN 0258-7122

Bangladesh J. Agril. Res. 40(3): 347-361, September 2015

\title{
FARMERS LAND TENURE ARRANGEMENTS AND TECHNICAL EFFICIENCY OF GROWING CROPS IN SOME SELECTED UPAZILAS OF BANGLADESH
}

\author{
ISLAM M. A. ${ }^{1}$ AND MAHARJAN K. L. ${ }^{2}$
}

\begin{abstract}
There are different land tenure arrangements in crop cultivation in Bangladesh. It is needed to detect how farmers could maximize the benefits from proper utilization of their resources and technologies in these prevailing different land tenure arrangements in crop cultivation. The main quest of this study is to analyze the actual production level and how much is deviated from maximum attainable production level in terms of technical efficiencybased on average gross revenue of output ha- ${ }^{1}$ in the cultivated various types of crops among different categories of farmers and identifies the impact of the factors associated with technical efficiency.In search of this research question a case study was conducted in two Upazilas (Sub districts) in Bangladesh based on cross section data. This data were collected from January to March, 2013. Age of the household head, education, farm size, off-farm income and other concerned issues were assessed. Maximum likelihood estimation and ordinary least square regression techniques were used to estimate the parameters of the stochastic production frontier.Ordinary least square regression was used to identify the factors associated with technical efficiency. The study reveals that the technical efficiency varied among different categories of farmers. But land rent $(0.0575)$ and weed management $(0.0838)$ had significant positive impact on technical efficiency. This detects the potentiality to improve the technical efficiency by taking proper measures in land tenure arrangements in consideration of land rent andprovide required weed management support for the farmers.
\end{abstract}

Keywords: Stochastic frontier approach, Maximum likelihood estimation, ordinary least square regression method, land tenure, agricultural production.

\section{Introduction}

Bangladesh is an agricultural developing country. The total area of Bangladesh is 144,000 sq. $\mathrm{km}$, population is 150 million having cultivable area of 8.44 million hectare (ha), the contribution of agriculture sector in the share of gross domestic product is $23.50 \%$, and this sector ensures $52 \%$ of the total employment of the

${ }^{1}$ Senior Assistant Secretary (OSD), Ministry of Public Administration, Bangladesh Secretariat, Dhaka, Bangladesh, Presently, Ph.D Student, Graduate School for International Development and Cooperation, Hiroshima University 1-5-1 Kagamiyama, Higashi-Hiroshima, 739-8529 Japan, ${ }^{2}$ Professor, Graduate School for International Development and Cooperation, Hiroshima University 1-5-1 Kagamiyama, HigashiHiroshima, 739-8529 Japan. 
country(BBS, 2011).The major cultivated cereal crops in Bangladesh areHYV Boro, T. Aman and B. Aman. The average yield of these crops are 3.90, 2.26 and 1.90 Ton ha- $^{-1}$ (BBS, 2011).The following three farming categories are observed in the country based on share cropping, fixed rent and mortgaging tenancy arrangements:(a) Owner farming (b) Owner cum tenant farming(c) Tenant farming.

\section{Farming category in the study areas}

In Bangladesh, the percentages of owner, owner cum tenant and tenant farmers are $65 \%, 22 \%$ and $13 \%$ respectively( BBS , 2011). Where as these percentages of owner, owner cum tenant and tenant farmers in the study areas are $44.5 \%, 33.5 \%$ and $22 \%$ respectively (DAE, 2013).

Owner farmers cultivate owned land and mortgaged land in owner farming. In cultivating this owned land, owner farmers get the whole amount of the produced crop as net revenue after deducting the production cost. In the case of mortgaged land, cultivators need not to pay any share of the produced output to the land owner but need to pay a certain amount of mortgaged money and duration of this mortgaged land persist until the mortgaged money can be repaid by themortgagor(who mortgaged out the land).

Owner cum tenant farmers cultivate owned land, mortgaged land, fixed rentedland and share cropped land. In cultivation of this fixed rented land, a fixed amount of money is needed to payannually to the land owners by the cultivators(who rented in the land in fixed renting system).The terms and conditions of mortgaged land in owner cum tenant farming are as same as mortgaged land in owner farming. In most cases, share cropping system of cultivation has been found inefficient in terms of low resource use, low productivity and deprivation from land lords.ThereforeBangladesh government passed the land reform ordinance 1984 in order to protect the interest of tenant or share croppers from landlords as well as to increase crop productivity at farm level through efficient use of resources.

According to this land reform ordinance of Bangladesh, tenant will provide labor, land will be provided by the land owner and rest other input costs will be shared between the land owner and tenant farmers in 50:50 ratio, and the produced output will be shared based on the same ratio between the land owner and tenant farmers to get proper incentive in agricultural production(LRB, 1982). But in practice, output sharing is conducted according tothis legal provision but input costs sharing is not practiced properly(Ullah, 1996). Again,this crop sharing arrangement is applied in case of share cropped land of the owner cum tenant farmers also. 
Measuring technical efficiency is one of theapproachesfor understanding how farmers could maximize the benefits from the proper utilization of existing resources and technologies. This approach can be conducted using production, cost or profit function. The first approach is called technical efficiency(Battese and Coelli,1995).

The adaptation of proper variety and other socioeconomic factors had significant impact on technical efficiency (TE) in rice production of different farming system in Bangladesh,Barmon (2013)found that farmers producing modern variety of rice were more technically efficient than farmers producing rice in prawn gher(Area used for prawn cultivation) farming in the coastal region of Bangladesh.

The mean technical efficiency of Nepalese rice seed growers was $81 \%$ and it was found that there was a wide variation in technical efficiency due to education level and experience of the farmers in seed production (Khanal and Maharjan, 2013). The mean technical efficiency of rice cultivation in Bangladesh was $69 \%$, indicating that there is a scope of $31 \%$ improvement in technical efficiency and availability of credit was found significant positive impact on technical efficiency (Ahmed, 2011). There are variations in the level of technical efficiency in agriculture within the sub- sectors of crop, livestock and fish cultivation. It is revealed that credit had a significant positive impact on the technical efficiency of all of these sub-sectors (Ahmed, 2010). The noted literatures clearly demonstrate that the stochastic frontier approach is widely used in agricultural economics studies. In case of Bangladesh, it was observed that fragmentation of land generates production inefficiency in agriculture sector (Wadud, 2003).In this study it was also found that farmers could increase their rice production by 9 to $39 \%$ if they could operate at full technical efficiency level with their existing resources and technology.

The pattern of land ownership affects gross revenue per hectare by affecting the efficient use of inputs. Considering the tenancy status of farm lands in Bangladesh, $58 \%$ of the land is operated by owner, $40 \%$ by owner cum tenant, and $2 \%$ by tenant farmers (Tenaw, et al., 2009).

There are studies (Ahmed, 2012; Asadullah, 2005) about land tenure and tenancy system in Bangladesh refuting the claim about the significance of land leasing in and consequence enhancements in viability of small farms. It is cited evidence that the terms of tenancy in Bangladesh were very oppressive. In large portion of the cases the land owner exacted $50 \%$ of the produced crops as rent without sharing any parts of the cost and at least $5 \%$ of the cases the share of rent was more than 50\%. Thus, when full cost accounting is applied the share croppers incurred a negative return (Ullah, 1996). The effect of land fragmentation on China's agriculture was examined by Wan and Cheng (2001) and found that a 
new land tenure institution emphasizing consolidation significantly improves the production efficiency. The mean technical efficiency of Nigerian agriculture was $77 \%$; it means that there is a scope of $23 \%$ improvement in technical efficiency (Idiong, 2007).

The productivity of agricultural production may varyamong different categories of farming due to discriminate use of various production inputs and managerial factors in Bangladesh, which needs proper evaluation through econometric model.There are some studies about various aspects of agricultural production in Bangladesh including technical efficiency based on different socioeconomic issues,but an updated study is needed on technical efficiency based on land tenure aspect to trace out the proper policy implication for the agricultural development in Bangladesh.Therefore, the present study was conducted with the following specific objectives.

\section{Objectives of the study}

- To analyze the technical efficiency of different categories of farmers in cultivating various cultivated crops in a cropping year to detect the actual production level and deviated from the maximum attainable production level of the farmers;

- To identify the impact of the factors influencing technical efficiency of different categories of farmers;

○ To recommendfor betterment of agricultural production;

\section{Materials and Method}

(a) Description of the Study location and sampling technique adopted:This study was carried out at Basailupazila ofTangail district and TitasupazilaofComilla district in Bangladesh. The area of Basailupazila was 158 sq.km, and population was 76,002.The area of Titasupazila was 107.19 sq.km, and population was 183,425 .These two Upazilas were selected as farmers of these twoUpazilas were getting proper agricultural support of the government due to location advantage, which can represent the overall farming characteristics of the country.The purposive stratified sampling technique was followed as the share of owner, owner cum tenant and tenant farmers were very disproportionate in the study areas(DAE, 2013).

(b) Method of data collection and period of study:Three hundred respondents were taken equally one hundred for each category and fifty respondents from each upazila.Data were collected in survey methodfrom January, 2013 - March, 2013 to trace out the proper factors oftechnical efficiency under different land tenure arrangements based on the cultivated 
crops in a cropping year. The major cultivated crops in the study areas were HYV Boro, T. Aman and B. Aman. Mustard, jute, wheat or pulses were cultivated as minor crops. Normally two or three crops were cultivated in each plot of land among these crops in a year.

(c) Analytical technique adopted: The collected data were analyzed by using STATA9.Stochastic frontier model was used to measure the technical efficiency of the different categories of farmers based on their average gross revenue of output ha- ${ }^{1}$ in the cultivated various types of land.This study considers the stochastic frontier approach with the assumption that the actual production cannotexceed the maximum possible production with the given input quantities and it is suggested to determine the factors responsible for inefficiency (Aigner et al.,1977 and Meeusen and van den Broeck,1977).

It was used in a two stage procedure. In the first stage,TE was computed and in the second stage socioeconomic variables of farm households were regressedagainst this TE using ordinary least square(OLS) regression method to identify their impact.Since the value of $\mathrm{TE}$ is $0<\mathrm{TE}<1$, it justifies using OLS technique(Kalirajan,1999;Piya,Kiminami and Yagi,2012).The stochastic frontier model used in this study as follows:

$L n_{\mathrm{Yi}}={ }_{\beta 0}+{ }_{\beta} \operatorname{Lnxi}+v i-u i \ldots$

Where, logarithm Yi is theaverage gross revenue of output ha- ${ }^{1}$ in different types of cultivated land, ${ }_{\beta}$ is the vector of parameters to be estimated,xi presents inputs.

These inputs includes per hectare averagecost of labor, power tiller, chemical fertilizer andirrigation in various categories of cultivated land of the different tenure groups of farmers. Land rent was taken as a proxy indicator of surplus as ownership patterns as well as cultivated land categories were different among owner,owner cum tenant and tenant farmers. This land rent was taken at the rate of the cost of mortgaged land of the owner farmers based on their cultivated mortgaged land, but for the owner cum tenant and tenant farmers this land rent was taken at the rate of cost of cultivated share cropped land of the owner cum tenant and tenant farmers in the study areas.

It was found in the study areas that if half of the seed cost was provided to the tenant by the land owner then land owner claimed half of the produced byproduct, and even sometimes without sharing this seed cost the half of the produced by- product was claimed also based on customary rule. To avoid this complexity, the price of by-product was not taken into account in estimating gross revenue as well as seed was not included due to this reason. $v_{i}$ presents the error term accounting for random variation in gross revenue due to factors outside the control of farmers. 
Another error term $u_{i}$ presents error associated with farm level inefficiency and this is assumed to have 0 mean with variance $(\sigma \mathrm{u} 2)$ and distributed half normally. Similarly, $\mathrm{v}_{\mathrm{i}}$ is assumed to have zero mean and constant variance $(\sigma \mathrm{v} 2)$ and distributed normally with independent with each $\mathrm{u}_{\mathrm{i}}$. Both of these error terms are supposed to be uncorrelated with explanatory variables $\mathrm{x}_{\mathrm{i}}$.

The loglikelihood function for half normal model is given in equation (2).This likelihood function estimates whether the variation among the observation is due to inefficiency. From the likelihood function we get $\sigma 2$ and $\lambda 2$.

Where, $\lambda 2=\sigma u 2+\sigma v 2$ and $\lambda 2=\sigma u 2 / \sigma 2$. If $\lambda=0$, it indicates there is no inefficiency effect and the variation in the data is due to random noise only. The higher the valueof $\lambda$ the more will be inefficiency effects explained by the model.

$\operatorname{Ln} L(Y i \mid \beta, \sigma \lambda)=-\frac{1}{2} \operatorname{Ln}(\pi \sigma 2)+\sum_{i=1}^{n} \operatorname{Ln} \emptyset\left\{\frac{-\varepsilon i \lambda}{\sigma}\right\}_{-2 \sigma} \frac{1}{2 \sigma 2} \sum_{i=1}^{n} \varepsilon i 2 \ldots$

Where, Yi is the vector log ofaverage gross revenue of output ha- ${ }^{1}$ in different types of cultivated land $\varepsilon i=v i-u i=\operatorname{Ln}$ Yi-xi $\beta$ is the composite error and $\emptyset(x i)$ is a cumulative distribution functionof the standard normal variable evaluated at xi.

\section{Empirical model:}

\section{Empirical model for production}

$\ln Y_{i}=a_{+} b_{1 \ln } X_{1}+b_{2 \ln } X_{2}+b_{3 \ln } X_{3}+b_{4 \ln } X_{4}+U_{i}$

Where,

$Y=$ Average gross revenue of output $\left(\right.$ Takaha $^{-}{ }^{1}$ ) of different types of cultivated land in different types of farming

$\mathrm{a}, \mathrm{b}_{1}, \mathrm{~b}_{2}, \mathrm{~b}_{3}, \mathrm{~b}_{4}=$ Parameters to be estimated

$\mathrm{X}_{1}=$ Average cost of labor (Taka ha- ${ }^{1}$ )in different types of cultivated land

$\mathrm{X}_{2}=$ Average cost of power tiller (Taka ha- ${ }^{1}$ )in different types of cultivated land

$X_{3}=$ Average cost of chemical fertilizer $\left(\right.$ Taka ha- $\left.{ }^{1}\right)$ in different types of cultivated land

$\mathrm{X}_{4}=$ Average cost of irrigation (Taka ha- ${ }^{1}$ )in different types of cultivated land

$\mathrm{U}_{\mathrm{i}}=$ Error term

\section{Empirical model for TE}

The TE of the farmers in the context of stochastic frontier model can be expressed as:

$\mathrm{TEi}=\frac{Y i}{Y^{*}}=f(x i ; \beta) \exp (\mathrm{v} i-u i) / f(x i ; \beta) \exp (v i)=\exp (-u i) \ldots$ 
Where, $Y *$ is the maximum possible average gross revenue of output ha- ${ }^{1}$ in different types of cultivated land,Yi,xi, $\beta, v i, T E i$ and uiare as explained earlier.TEi measures the average gross revenue of output ha- ${ }^{1}$ in different types of cultivated land of the farmers relative to the maximum possible average gross revenue ofoutput ha- ${ }^{1}$ in different types of cultivated land that can be produced using the same cost of input vectors. This value of TEi is 0 to 1 .

If $\mathrm{TEi}=1, \mathrm{Yi}$ achieves the maximum value of $f(x i ; \beta) \exp (v i)$.IfTEi is less than 1 , thatindicates the shortfall of gross revenue of output from the maximum possible level.Thissituation is characterized by stochastic elements, which vary among the farmers.The following equation (4) was used to identify the impact of socioeconomic variables on TE.

$T E i=\delta_{0}+\delta \operatorname{Ln} Z i+\omega_{i} \quad \ldots(4)$

Where, $\delta$ presents the parameters associated with socioeconomic variables(zi), and $\omega_{i}$ is the error term.

The variables for the study were chosen considering both production theory and local context of the farmers. Analysis of variance (ANOVA) was used to analyze the mean difference of technical efficiency of the farmers.

Regression analysis was used to identify the impact of the factors associated with technical efficiency.In using this stochastic frontier model Wald chi ${ }^{2}$ test showed significant result $(\mathrm{P}=0.0000)$, that indicates the fitness of the model. All of these stochastic frontier model, ANOVA and regression analyses were used based on overall study areas.For the regression analysis OLS method was used, because OLS is easier to analyze mathematically than many other regression technique. It produces solution those are easily interpretable; OLS is the best unbiased linear estimator of the model coefficient.

Moreover, robust regression technique of this OLS model mitigates the problem of data variation. Before running this OLS model data were validated using Variance Inflation Factor(VIF) and robust regression method for multicollinearity and heteroskedasticity.

This OLS model was used in the many other similar studies including the study conducted by Ahmed (2012),on Agricultural Land Tenancy. This OLS model was also used in the study on Farm Productivity and efficiency in Rural Bangladesh: The role of Education Revisited(Asadullah,2005).

\section{Results and Discussion}

\section{(1) Socioeconomic characteristics of respondent farmers}

Table 1 presents the socioeconomic characteristics of the respondent farmers. The average year of education of head of the household $\left(\mathrm{HHH}^{1}\right)$ were $4.65,3.96$ 
and 2.22 in owner, owner cum tenant and tenant farmers respectively. This year of education varied from 0 to 14 years, from 0 to 10 years, and from 0 to 5 years in owner, owner cum tenant and tenant farmers respectively.

The average farm size of owner, owner cum tenant and tenant farmers were 0.77 , 0.74 and 0.70 ha respectively.This farm size varied in owner, owner cum tenant and tenant farmers from 0.23 to 4.08 ha, from 0.23 to 2.27 ha and from 0.23 to 2.72 ha respectively.

The mean land rents were BDT 18,010, 9,730 and 16,050 ha ${ }^{-1}$ among owner, owner cum tenant and tenant farmers respectively.This land rent varied from BDT 8,000 to 83,803, from BDT 5,000 to 39,696 and from BDT 3,000 to75,000, ha $^{-1}$ respectively.

The percentages of adoption of new crop adopting farmers were 100, 100 and 87 among owner, owner cum tenant and tenant farmers respectively. But this percentage was 96 in overall.

The percentages of weed management adopting farmers were 100, 98 and 5 amongowner, owner cum tenant and tenant farmers, but this percentage was 68 in overall.

From the discussion of socioeconomic characteristics of the farmers, it is concluded that tenant farmers were in most dis-advantageous position in farming among these different tenure categories of farmers in consideration of farm size and all other socioeconomic aspects.

\section{(2) Study variables}

Table 2.1presentsthe mean and standard deviation of the study variables.The mean gross revenues of owner, owner cum tenant and tenant farmers were BDT $94,558,93,941$ and103,916ha ${ }^{-1}$ respectively.

Those varied from BDT15,845 to 234,650 , BDT 25,641 to 395,200 and BDT 11,115 to 185,250

ha $^{-1}$ inowner, owner cum tenant and tenant farmers respectively.The mean labor costs of owner, owner cum tenant and tenant farmers were BDT7,133,4,438 and 10,938 ha $^{-1}$ respectively. These labor cost varied in the range of BDT 2,205 to 16,540 , BDT 2,205 to 11,026 and BDT1,500 to 16,540 among owner, owner cum tenant and tenant farmers respectively. The mean power tiller costswere BDT $2,419,1,626$ and 4,084 $\mathrm{ha}^{-1}$ in owner, owner cum tenant and tenant farmers respectively.

This power tiller cost varied from BDT 1,470 to 4,410, BDT1,143 to 4,410and BDT1,700to $4,940 \mathrm{ha}^{-1}$ in owner, owner cum tenant and tenant farmers respectively. 


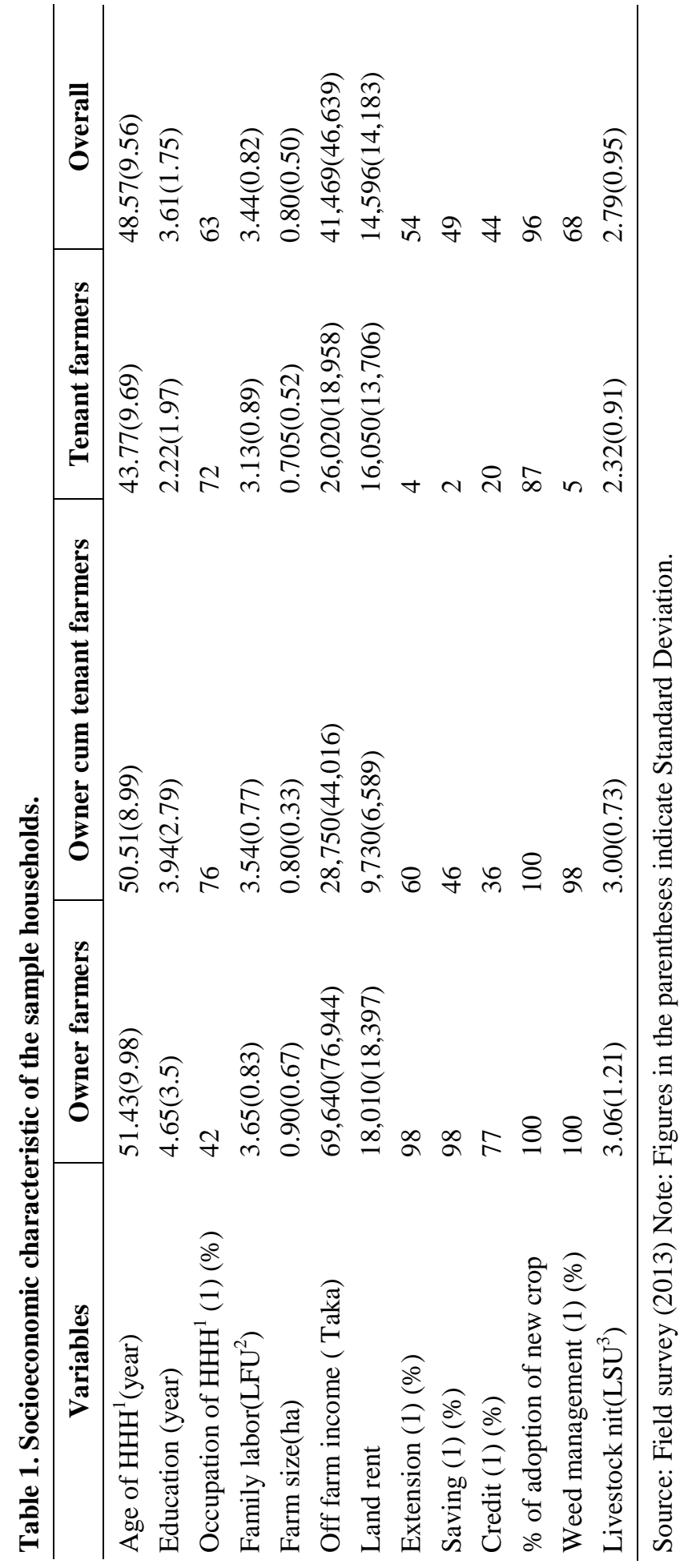


The mean fertilizer costs were BDT8,659, 4,942 and12,312 ha ${ }^{-1}$ in owner,owner cum tenant and tenant farmers respectively. This fertilizer cost varied from BDT 1,929 to 19,848 , BDT653 to 6,076and BDT 3,193 to18,525 ha ${ }^{-1}$ in owner,owner cum tenant, and tenant farmers respectively.The mean irrigation costswere BDT $6,435,3,795$ and $9,316 \mathrm{ha}^{-1}$ in owner, owner cum tenant and tenant farmers respectively. This irrigation cost varied from BDT 1,874 to 11,026 , BDT 1,176 to 7,351 and BDT 2,940 to $16,540 \mathrm{ha}^{-1}$ in owner, owner cum tenant and tenant farmers respectively. This cost of production varied in different categories of farmers due to crop cultivation without tillage system and other concerned issues.

Table 2. Mean and standard deviation (SD) of the study variables use in stochastic frontier model.

\begin{tabular}{|c|c|c|c|c|c|c|}
\hline \multirow{2}{*}{ Variables } & \multicolumn{2}{|c|}{ Owner } & \multicolumn{2}{|c|}{$\begin{array}{l}\text { Owner cum } \\
\text { tenant }\end{array}$} & \multicolumn{2}{|c|}{ Tenant } \\
\hline & Mean & SD & Mean & SD & Mean & SD \\
\hline Yield( gross revenue Taka ha- ${ }^{1}$ ) & 94,558 & 38,213 & 93,941 & 34,489 & 103,916 & 33,501 \\
\hline Labor (cost Taka ha- ${ }^{1}$ ) & 7,133 & 1,937 & 4,438 & 1,080 & 10,938 & 3,791 \\
\hline Power tiller (cost Taka ha- ${ }^{1}$ ) & 2,419 & 650 & 1,626 & 595 & 4,084 & 842 \\
\hline Chemicalfertilizer(cost Taka ha- $\left.{ }^{-1}\right)$ & 8,659 & 2,996 & 4,942 & 1,240 & 12,312 & 5,560 \\
\hline Irrigation/ IC $^{4}\left(\operatorname{cost}\right.$ Taka ha- $\left.{ }^{1}\right)$ & 6,435 & 1,571 & 3,795 & 1,223 & 9,316 & 4,063 \\
\hline
\end{tabular}

Source: Field survey (2013) Note: The name of Bangladesh currency is Taka, BDT= Bangladesh Taka, 1 US Dollar=77.98 BDT.

\section{(3) Factors Affecting Goss Revenue}

Table 3 presents the findings from stochastic frontier model. The significant loglikelihood using the wald test signified the fitness of the model $(\mathrm{P}=0.0000)$. Moreover, the likelihood ratio test for the absence of inefficiency in the model criteria was rejected $(\mathrm{P}=0.000)$. Indicating that the inefficiency effect explained in the model was higher than random noise. It was also estimated marginal effects of the relevant input variables on gross revenue to complement the analysis and these marginal effects were used to discuss the average impact of inputs on gross revenueof the farmers. Labor and chemical fertilizerhadpositive effect. But power tiller and irrigation $\left(\mathrm{IC}^{4}\right)$ had negative effect on gross revenue. The marginal effect of labor was 0.226 ,indicates that $1 \%$ increase in labor cost leads to increase average gross revenue of output ha- ${ }^{1}$ by $0.226 \%$. The marginal effect of fertilizer was 0.103 , indicates that $1 \%$ increment of fertilizer cost leads to increase the average gross revenue of output $\mathrm{ha}^{-1}$ by $0.103 \%$. The marginal effect of power tiller was -0.452 , indicates that $1 \%$ increase in power tiller cost leads to decrease the average gross revenue of output ha- ${ }^{1}$ by $0.452 \%$. The marginal effect of irrigation was -0.052 , indicates that $1 \%$ increment in irrigation cost leads to decrease the average gross revenue of output ha- ${ }^{1}$ by $0.052 \%$. 
Table 3. Maximum likelihood estimates and marginal effect.

\begin{tabular}{llll}
\hline \multicolumn{1}{c}{ Variables } & \multicolumn{1}{c}{ Coefficients } & \multicolumn{1}{c}{ P value } & \multicolumn{1}{c}{ Marginal effects } \\
\hline Labor & $0.306(0.000021)$ & $0.000 * * *$ & 0.226 \\
Power tiller & $-0.690(0.000014)$ & $0.000 * * *$ & -0.452 \\
Chemical fertilizer & $0.138(0.000019)$ & $0.000 * * *$ & 0.103 \\
Irrigation( $\left(\mathrm{IC}^{4}\right)$ & $-0.072(0.000021)$ & $0.000 * * *$ & -0.052 \\
Constant & $14.36(0.00011)$ & $0.000 * * *$ & \\
\hline
\end{tabular}

Loglikelihood:-298.05*** $\sigma^{2}=1.71 \lambda=7.77$ likelihood ratio $=2.7 * * * \mathrm{~N}=300, * * *$ indicates significant at $1 \%$ level of significance.

\section{(4) Farm specific technical efficiency of the farmers}

Tables $(4.1,4.2)$ present frequency distribution and mean difference of technical efficiency among owner, owner cum tenant and tenant farmers. From the tables it is found that there was a variation among the number of farmers as well as significant mean difference of technical efficiencyamong owner, owner cum tenant and tenant farmers.

Table 4.1 Frequency distribution of farm specifictechnical efficiency of the farmers.

\begin{tabular}{l|c|c|c}
\hline \multicolumn{1}{c|}{ Rage of TE } & Owner(\%) & $\begin{array}{c}\text { Owner cum } \\
\text { tenant }(\%)\end{array}$ & Tenant(\%) \\
\hline$<0.50$ & 29 & 70 & 50 \\
$0.51-0.60$ & 28 & 12 & 28 \\
$0.61-0.70$ & 18 & 06 & 09 \\
$0.71-0.80$ & 06 & 08 & 03 \\
$0.80^{+}$ & 19 & 04 & 10 \\
\hline
\end{tabular}

Table 4.2 Farm specific technical efficiency of the farmers.

\begin{tabular}{|c|c|c|}
\hline Farming category & Technical efficiency & $P$ value \\
\hline Owner & $0.603(0.211)$ & $0.0000 * * *$ \\
\hline Owner cum tenant & $0.444(0.184)$ & \\
\hline Tenant & $0.527(0.192)$ & \\
\hline
\end{tabular}

Note: Number of observation: $300 * * *$ Significant at $1 \%$ level of significance, figures in the parentheses indicate Std. Dev.

The result shows that there was $60 \%$ mean technical efficiency of owner farmers that varied from $7.9 \%$ to $99.9 \%$. Indicates that owner farmers could improve technical efficiency by $40 \%$. This mean technical efficiency in owner cum tenant farmers was $44 \%$ that varied from $3.8 \%$ to $99.9 \%$, indicates that owner cum tenant farmers could improve technical efficiency by 56\%. Again average technical efficiency of tenant farmers was $52.7 \%$ in the range of $5.8 \%$ to $99.9 \%$, which indicates that tenant farmers could improve technical efficiency by $47.3 \%$. 


\section{(5) Factors affecting technical efficiency of the farmers}

Table 5 presents the summary result of the impact of socioeconomic variables.We tested fourteen socio economic explanatory variables against technical efficiency in OLS regression. From the analysis, it was found that the direction of the response of the variables land rent andweed management were as per the hypothesis and these variables hadsignificant positive impact on technical efficiency.Indicate that $1 \%$ increment of land rent leads to increase TE by $5.75 \%$.This might be for the better incentive of land rent as a surplus in farming. Proper use of weed management leads to increase TE by $0.0838 \%$. This might be better utility of weed management in farming.Education, farm status, farm size and adoption of new crop were significant but did not show expected sign.

Table 5. Measurement unit, expected sign and parameter estimates of the OLS model.

\begin{tabular}{|c|c|c|c|c|}
\hline Variables & Measurement unit & $\begin{array}{l}\text { Expected } \\
\text { sign }\end{array}$ & Coefficients & $P$ value \\
\hline Age of the $\mathrm{HHH}^{1}$ & Year & + & $0.0015(.001)$ & 0.264 \\
\hline Education & Year of formal education & + & $-0.0128(.004)$ & $0.003 * * *$ \\
\hline Occupation & $\begin{array}{l}1=\text { primary, } 0=\text { secondary } \\
(\text { dummy) }\end{array}$ & + & $-0.0146(.030)$ & 0.634 \\
\hline $\begin{array}{l}\text { Farm status (Owner } \\
\text { cum tenant) }\end{array}$ & $2=$ owner cum tenant & + & $-0.0797(.032)$ & $0.015 * *$ \\
\hline Farm status( Tenant) & $3=$ tenant & + & $0.0431(.059)$ & 0.467 \\
\hline Family labor(LFU²) & $\mathrm{LFU}^{2}$ & + & $0.0110(.015)$ & 0.466 \\
\hline Ln farm size & Hectare & + & $-0.0857(.023)$ & $0.000 * * *$ \\
\hline Ln off- farm income & BDT & + & $-0.0212(.016)$ & 0.198 \\
\hline Ln land rent & BDT & + & $0.0575(.019)$ & $0.003 * * *$ \\
\hline Extension services & $1=$ Yes, $0=$ No (dummy) & + & $0.0452(.035)$ & 0.208 \\
\hline Saving & $1=$ Yes, $0=$ No (dummy) & + & $0.0392(.037)$ & 0.296 \\
\hline Credit & $1=$ Yes, $0=$ No (dummy) & + & $0.0386(.032)$ & 0.233 \\
\hline $\begin{array}{l}\text { Adaptation of new } \\
\text { crop }\end{array}$ & $1=$ Yes, $0=$ No (dummy) & + & $-0.1202(.061)$ & $0.053 *$ \\
\hline Weed management & $1=$ Yes, $0=$ No (dummy) & + & $0.0838(.039)$ & $0.034 * *$ \\
\hline $\begin{array}{l}\text { Livestock unit } \\
\text { (dummy) }\end{array}$ & $\mathrm{LSU}^{3}$ & + & $-0.0205(.015)$ & 0.196 \\
\hline Cons & BDT & + & $0.1812(.261)$ & 0.488 \\
\hline
\end{tabular}

Note: Farm status:1= owner, 2= owner cum tenant, 3= tenant (dummy) Number of observation: $300 \mathrm{R}$-squared $=28$ Root $\mathrm{MSE}=0.176$ Figures in the parentheses indicate Std. Err. $* * *, * *$ and $*$ Significant at $1 \%, 5 \%$ and $10 \%$ level of significance respectively. 
In case of education, this might be the provided education was not properly oriented in farming. For the case of farm status of owner cum tenant farmers, this might be due to extensive use of owned land of owner cum tenant farmers. For farm size, this might be due to extensive use of owned land of the owner farmers as well as owner cum tenant farmers. In the case ofadoption of new crop, this might be the existing cultivation of crop is economically more viable than adoption of new crop based on the socioeconomic context of the farmers. Other variables did not show significant impact on technical efficiency.

\section{Conclusion and recommendation}

In this study technical efficiency of different categories of farmers was estimated using stochastic frontier model and analyzed the estimated technical efficiency using ANOVA.It was found that there was a statistically significant difference from zero in the level of technical efficiency among owner, owner cum tenant and tenant farmers.It was alsofound significantly positive influence of landrent and weed management on technical efficiency.

From the discussions it can be discerned that, there is a potentiality for the enhancement of technical efficiency in ensuring change by taking measures in land tenure arrangements in proper implementation of the land reform ordinance 1984 that will ascertain higher surplus for the share croppersin share cropped land and provide weed management support for the farmers. Those might lead to attain higher technical efficiency. This study recommends the government to take necessary measures on that direction.

\section{End Note:}

(1) HHH stands for household head.

(2) Labor force unit(LFU) is the measurement of family labor where people from 15-59 years regardless of sex were categorised 1 person=1 LFU, but in the case of children 10-14 and elderly people more than 59 years old 1 person $=0.5 \mathrm{LFU}$.

(3) Livestock unit(LSU) is the aggregate of different types of livestock kept at household standard unit calculated using following equivalents;

1 adult buffalo $=1$ LSU, 1 immature buffalo $=0.5 \mathrm{LSU} 1 \mathrm{cow}=0.8 \mathrm{LSU}$, 1 sheep or goat $=0.2 \mathrm{LSU}$ and 1 poultry or pigeon=0.1 LSU (Khanal and Maharjan,2013).

(4) IC stands for irrigation cost. This irrigation cost is paid in kind as one fourth of the total produced crop. 


\section{References}

Ahmed, S. 2012. Agricultural Land Tenancy in Rural Bangladesh: Productivity Impact and Process of Contract Choice.

Ahmed, M. S. 2010. Technical Efficiency of Agricultural Farms in Khulna, Bangladesh: Stochastic Frontier Approach.

Asadullah, N. M. 2005. Farm Productivity and Efficiency in Rural Bangladesh: The Role of Education Revisited SKOPE, Department of Economics Uiversity of Oxford, UK.

Bangladesh Bureauof Statistics (BBS). 2011. Year Book of Agricultural Statistics of Bangladesh Bureau of Statistics, Ministry of Planning, Government of the people`s republic of Bangladesh, Dhaka.

Barmon, B.K. 2013. Technical Efficiency and Total Factor Productivity of Modern Variety Paddy Production UnderDifferent Farming System in Bangladesh, Asia Pacific Journal of Rural Development 1: 58-78.

Bamatraf, A. R. 2000.Impact of Land Tenure and other Socioeconomic Factors on Mountain Terrace Maintenance in Yemen, International Food Policy Research Institute, Washington D.C, USA.

Bilkis, R. 2012. Trend in Productivity Research in Bangladesh Agriculture: A Review of Selected Articles, Asian Business Review, volume 1.

Battese, G. E., and Coelli, T. J. 1995. A model for Technical Inefficiency Effect in a Stochastic Frontier Production Function for Panel Data, Empirical Economics, 20(1995): 325-332.

Department of Agricultural Extension (DAE). 2013. Department of Agriculture Extension, Tangail and Comilla districts, Bangladesh.

Hossain, M. 1991.Agriculture in Bangladesh: Performance Problems and Prospects University press limited.

Idiong, I. C. 2007.Estimation of Farm Level Technical Efficiency in Small Scale Swamp Rice Production inCross River State of Nigeria: A Stochastic Frontier Approach, World Journal of Agricultural Sciences, (5):653-658.

Kalirajan, K. P. 1999. The Importance of Effective and Efficient Use in the Adoption of Technologies:A Micro Panel Data Analysis Journal of Production Analysis Pp. 113126.

Khanal, N. P., and Maharjan, K. L. 2013. Technical Efficiency of Rice Seed Growers in the Tarai region of Nepal, Journal of rural problems, 49(1):27-31.

Land Reform Board (LRB).1982. Land Reform Report of Land Reform Committee, Land Reform Board, Ministry of Land, Government of the People's Republic of Bangladesh, Dhaka.

Meeusen, W. and Van den Broeck, J. 1977.Efficiency Estimation from Cobb Douglas Production Function with Composed Error. International Economic Review, 18(2): 435-444. 
S. Piya. A. Kiminami and Yagi, H. 2012. Comparing the Technical Efficiency of Rice Farmers in Urban and Rural Areas: A Case Study from Nepal, Trends in Agriculture Economics, Pp. 48-60.

Tenaw, S., Islam, Z. K. M., Parviainen, T. 2009. Effects of Land Tenure and Property Rights on Agricultural Productivity in Ethiopia, Namibia and Bangladesh University of Helsinki, Department of Economics and Management, Helsinki, Finland.

Ullah, M. 1996. Land Livelihood and Change in Rural Bangladesh, University press limited.

Wadud, M. A. 2003. Technical, Allocative and Economic Efficiency in Bangladesh: A Stochastic and DEA approach, The Journal of Developing Areas, 37(1):109-126. 